\title{
Le diagnostic biologique de l'insuffisance cardiaque
}

\section{Insuffisance cardiaque et peptide natriurétique de type B}

Résumé du dossier en ligne

\section{Marie-Odile Benoit \\ Laboratoire de Biochimie \\ Cardio-Vasculaire}

Hôpital Européen Georges Pompidou 20/40 rue Leblanc, 75015 Paris

\begin{abstract}
'insuffisance cardiaque est l'aboutissement de la plupart des maladies cardiaques dont
\end{abstract} la prévalence et l'incidence ont considérablement augmenté ces dernières années. Son taux de mortalité est de $50 \%$ à 5 ans. Un diagnostic précoce et une mise rapide sous traitement peuvent avoir un impact majeur pour le patient (retard dans la progression de la maladie, amélioration des conditions de vie). La sécrétion du peptide natriurétique de type $B$ par les cardiomyocytes des ventricules, en réponse à une surcharge volémique a été montrée fortement liée aux différents stades de l'insuffisance cardiaque. La mise en évidence de ce peptide actif, le
BNP ou de la partie $\mathrm{N}$ terminale du prohormone est d'une grande importance pour le diagnostic précoce de l'insuffisance cardiaque, de même que dans le suivi thérapeutique de la maladie. De nombreuses études portent actuellement sur l'importance des concentrations de l'un ou l'autre de ces peptides dans la stratification des patients à haut risque et dans le devenir de leur prise en charge. Seules les techniques d'imagerie peuvent donner précisément l'origine de la maladie. De toutes les études comparant les différents marqueurs biologiques de l'insuffisance cardiaque, le BNP apparaît comme le meilleur marqueur diagnostique et pronostique de l'insuffisance ventriculaire gauche, diastolique ou systolique. L'introduction plus récente du dosage du NT-proBNP semble également rendre ce peptide très prometteur.

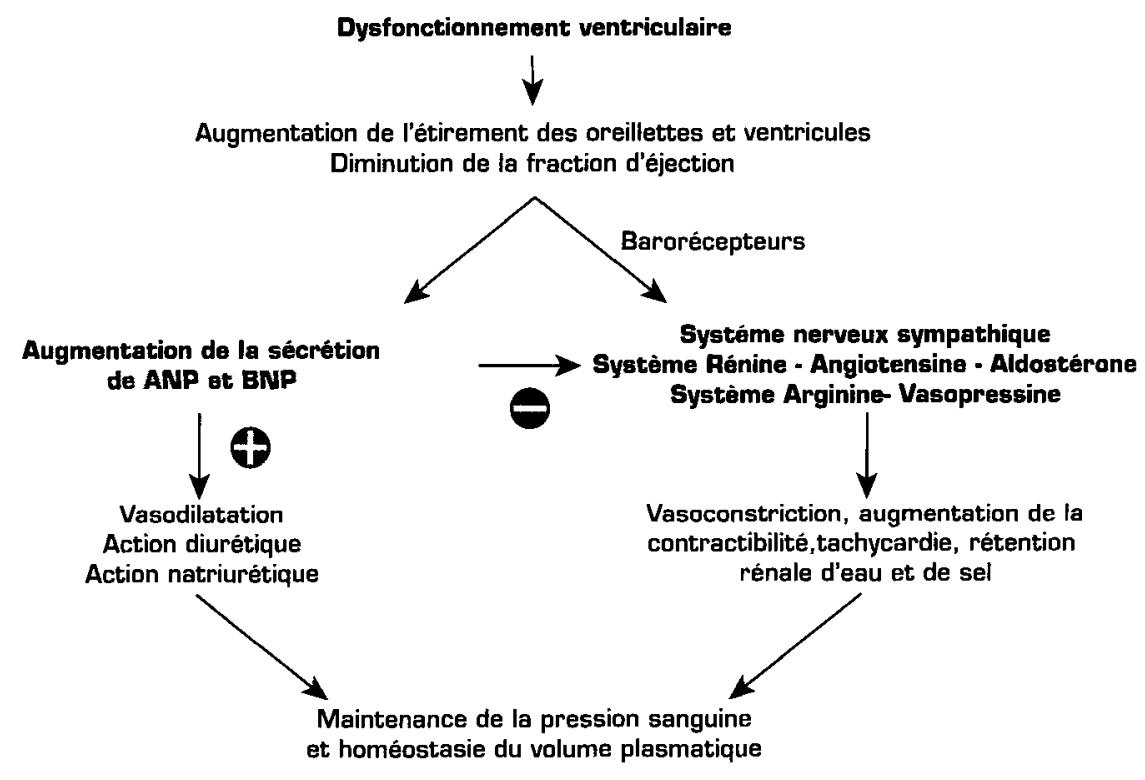

BioTribune.com vous propose de retrouver sur son espace thématique Cardiologie le dossier intégral du Docteur Marie-Odile Benoit, ainsi qu'un diaporama commenté, complet et détaillé sur les marqueurs de l'insuffisance cardiaque et de leur récepteurs : historique, dosages, alphabet des peptides natriurétiques, progrès du diagnostic biologique de I'insuffisance cardiaque... Par le Docteur Georges Chiche (cardiologue, Marseille). 